Paideusis

\title{
Democratic Paradoxes: Thomas Hill Green on Democracy and Education
}

\section{Darin R. Nesbitt and Elizabeth Trott}

Volume 15, Number 2, 2006

URI: https://id.erudit.org/iderudit/1072681ar

DOI: https://doi.org/10.7202/1072681ar

See table of contents

Publisher(s)

Canadian Philosophy of Education Society

ISSN

0838-4517 (print)

1916-0348 (digital)

Explore this journal

Cite this article

Nesbitt, D. \& Trott, E. (2006). Democratic Paradoxes: Thomas Hill Green on Democracy and Education. Paideusis, 15(2), 61-78.

https://doi.org/10.7202/1072681ar
Article abstract

This paper provides an account of the paradoxes of teaching democracy, the paradoxes of being a citizen in a liberal democracy, and the insights that can be gained from the model of citizenship that T.H. Green promoted. Green thought citizenship was predicated on the twin foundations of the community and the common good. Freedom for Green means individual self-determination coupled with recognition of the dependency relations between individuals and the community. Green is noteworthy not only as a theorist but also as an active contributor to the development of public schools in England. A consideration of his arguments provides a model for educating citizens, addresses the paradoxes of democracy in education, and reveals elements of his philosophy that are relevant to educational issues today.
(C) Darin R. Nesbitt, Elizabeth Trott, 2006

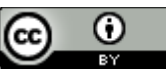

This document is protected by copyright law. Use of the services of Érudit (including reproduction) is subject to its terms and conditions, which can be viewed online.

https://apropos.erudit.org/en/users/policy-on-use/ 


\title{
Democratic Paradoxes: Thomas Hill Green on Democracy and Education
}

\author{
DARIN R. NESBIT'T and ELIZABETH TROT'T \\ Douglas College and Ryerson University, Canada
}

This paper provides an account of the paradoxes of teaching democracy, the paradoxes of being a citizen in a liberal democracy, and the insights that can be gained from the model of citizenship that T.H. Green promoted. Green thought citizenship was predicated on the twin foundations of the community and the common good. Freedom for Green means individual self-determination coupled with recognition of the dependency relations between individuals and the community. Green is notewortby not only as a theorist but also as an active contributor to the development of public schools in England. A consideration of his arguments provides a model for educating citizens, addresses the paradoxes of democracy in education, and reveals elements of his philosophy that are relevant to educational issues today.

\section{Introduction}

A serious problem confronting educators and policy-makers in advanced liberal-democracies is the issue of student apathy about political life. The declining voter turnout rate in Canada, for example, suggests a deepening cynicism about the ability and willingness of governments to address citizen concerns. What is more disconcerting is the cohort and generational effects of political disengagement. ${ }^{1}$ The publicity generated by government scandals, such as the misappropriation of public funds in the recent Canadian federal government sponsorship scandal, fuels scepticism. The representative model of democracy in which elected and appointed officials exercise substantial decision-making autonomy contrasts with the participatory model. The representative model is vulnerable to influence by powerful individuals and groups precisely because it is designed to moderate, even override, the judgment of citizens by that of elected officials, policymakers, and professionals. The decline of citizen confidence in government and its institutions threatens the process of forming democratic identities: informed, critically aware, and vigilant citizens who desire to participate as equals in public life and to be included in policy formation and decision-making.

There has been robust debate over the nature and role of the democratic citizen. As Mark Warren explains, thinkers such as James Madison, James Mill, Joseph Schumpeter, and more recently, neo-conservatives seek to balance democratic participation against other desirable goals, such as protecting rights and freedoms and governability by limiting the areas of society that are subject to democratic imperatives. Another group of thinkers such as Jean-Jacques Rousseau, John Stuart Mill, T.

\footnotetext{
${ }^{1}$ Adsett, 2003.

(C) Copyright 2006. The authors, Darin R. Nesbitt and Elizabeth Trott, assign to Paideusis the right of first publication and educational and non-profit institutions a non-exclusive license to use this document for personal use and in courses of instruction provided that the article is used in full and this copyright statement is reproduced. Any other usage is probibited without the express permission of the authors.
} 
H. Green, and John Dewey argue that those who seek to limit democracy in such a manner may themselves be accentuating some of the participatory problems by purposefully limiting citizen involvement. These differences, Warren continues, emerge partly as a result of differing assumptions about the self and its relations to political and social life. The one perspective conceives selves as individuals whose interests are not to be subjected to the vicissitudes of political life such as majority will or transformative social experiments. The other suggests that if individuals were more active and involved-particularly in institutions that most greatly affect their lives, such as schools and workplaces - citizens would become more publicly-spirited, tolerant, knowledgeable selves who would be better situated to reassess and articulate their own perspectives and interests. ${ }^{2}$

The sources of citizen discontent and apathy are diverse and complex, yet those who cast aspersions against liberal-democratic governments for this state of affairs need to reconsider other factors. One cause must be the way students are socialized to adopt their future roles as citizens. ${ }^{3}$ Students' educational experiences and self-understandings will shape their views on the efficacy of civic engagement. While educators and policymakers face mounting pressure to promote democratic values, the paucity of democratic pedagogy represents one of many paradoxes confronting educators today. The systematic review, discussion, and assessment of political institutions and the requirements of citizenship occur only once students enter colleges and universities. It cannot be a coincidence that the erosion of confidence in political institutions is occurring at the same time as public (and private) school systems are increasingly acceding to labour market imperatives by devoting more resources to courses and programs that emphasize so-called skills development. There are clear indicators that present educational thought and policies are resurrecting ideas and practices that thinkers long ago revealed as irredeemably flawed.

The centrality of education to the development of more tolerant, knowledgeable, and probing citizens is a topic of long-standing concern. The ideal of democratic education has two broad justifications that generate tensions if one is advanced at the expense or to the exclusion of the other. The first is the intrinsically good perspective that presumes education, as the generic pursuit of knowledge, is good in itself. The exploration of democratic values and beliefs such as tolerance, respect, equality, and freedom is defended as inherently worthwhile and necessary to conceptual and philosophical understanding. The second is the extrinsically good perspective. Education is valued for its ability to provide students basic functional skills such as reading and writing, and, at more advanced levels, applied research. Certainly democratic citizens must be sufficiently literate to meet the communicative demands of modern social and economic life. However, schools and teachers are increasingly under pressure to forge functionally literate individuals capable of finding gainful employment. While both the intrinsic and utilitarian justifications of education can conflict-particularly in the allocation and distribution of limited educational resources - there is no inherent and insurmountable chasm separating them.

If the purpose of education is to prepare young people for social life- a life that is about the intrinsic welfare of persons and about the extrinsic qualitative world in which they function-then the difficulty with privileging the extrinsically good perspective is that the intrinsic well-being of individual students becomes at best incidental but more likely irrelevant to the goals of education. ${ }^{4}$ Yet the extrinsically good perspective purports to include in its goals the value of democracy, a value it presumes educators and students will consider worthy of defence. Stephen Esquith uses the terms political clientism and political consumerism to express a dominant self-understanding of modern liberaldemocratic citizens. As political clients, liberal citizens depend on professionals, public planners, and policymakers for advice, assistance, and expert services. As political consumers, citizens reserve the

\footnotetext{
${ }^{2}$ Warren, 1992, pp. 8-9.

3 See, for example, Meirick \& Wackman, 2004; Sapiro, 2004; Dudley \& Gitelson, 2004; Patrick, 2002; Galston, 2001.

${ }^{4}$ Nicholson, 1990 , pp. $166-177$.
} 
right to make some final decisions for themselves. ${ }^{5}$ To presume that citizens are principally clients and consumers is to assume that the democratic values of choice and autonomy are intimately related to the intrinsically valued sense of being worthy, respected, and independent human beings. The connection between intrinsic worth and the social and political conditions of its preservation is not self-evident and consequently requires specific educational advocacy. The processes and goals of democratic politicsthe formal equality of citizens, the possibility that voters can replace governments, and the recognition and protection of basic rights and freedoms-require intrinsic justification.

As functioning systems, schools (and throughout this paper 'schools' typically refer to ones that precede universities and colleges) seldom stand as models of democracy. Hierarchical administrative procedures, official external bodies that approve curricula, and the power relations that define the classroom encounters between students and teachers demonstrate little connection to democratic theory and practices. Moreover, external pressures on schools (including colleges and universities) to adopt market-oriented measures to attract students and to justify education in terms of student selfinterest and material gain (which we regard as different from intrinsic welfare) can undermine a school's ability to inculcate democratic values such as equal rights and respect for others. Undoubtedly there are elementary or primary and secondary programs where students contribute to social service projects and conscientious teachers who promote these activities, but unless there is an overall policy directed towards understanding one's role as a citizen, such efforts may not have lasting impact.

This paper examines the educational visions of Thomas Hill Green (1836-1882) in order to better understand these issues and to revisit some paradoxes generated by the ideal of democratic education. Green supported a conception of a common good that shaped and informed his policy prescriptions. For Green, the telos of education was the creation of diverse individuals who were also active supporters of and participants in civic life. To achieve this objective, Green insisted educational practices must be universalistic - meaning inclusive-and exhibit greater uniformity of curricula goals. Access to knowledge is everyone's right: rich and poor, men and women. ${ }^{6}$ Curriculum should not be the secluded domain of specific religious interests but instead universal and non-denominational. Green advocated a democratization of education based on the principle of what will be described here as mutual independency. One of Green's most important observations was that the value of individuality could only be discerned in the context of other selves. The individual and society were not contrary but rather complimentary conceptions. The ideal of the citizen is the bridge between the individual and society. Being a citizen, Green argued, is integral to one's identity, not an occasionally assumed mantle.

\section{Background of T. H. Green}

Green was an influential scholar and reform-minded university administrator at Balliol College, Oxford. In 1855, at the age of nineteen, Green entered Balliol where his reputation as a great thinker was later established. In 1860, at the age of twenty-four, Green became a teacher at Oxford, lecturing on ancient and modern history at Balliol. Later that year he was elected fellow of Balliol, and subsequently was elected tutor in the fall of 1866. Green's crowning academic achievement was his appointment as White's Professor of Moral Philosophy in 1878. As a tutor, he was active in university affairs, particularly in initiating and campaigning for curricula and administrative reform. Green and his mentor Benjamin Jowett were instrumental in creating and delivering university extension programs at Oxford, and Green was the first administrator of an extension college attached to Balliol. He was an active

\footnotetext{
${ }^{5}$ Esquith, 1994, p. 43.

${ }^{6}$ For an assessment of Green's views on women's rights and his advocacy for higher education for women, see Leighton, 2004, pp. 302-309.
} 
promoter of a plan in 1867 to provide scholarships to help students and families who could not afford the cost of university at Oxford.

Green later publicly supported the National Education League in its calls for compulsory attendance, public funding of elementary schools, and non-sectarian instruction. He spoke in support of a resolution by the National Education League to agitate for a compulsory national system of nondenominational education. ${ }^{7}$ Throughout the 1870 s Green became more involved in elementary education within the city of Oxford. He frequently lamented that one of the finest universities in the world also was largely inaccessible to most of Oxford's residents. Green served on the School Board for Oxford Elementary Schools, and was a well-known advocate for the education of all children, boys and girls, at the elementary and secondary levels. Tellingly, the last public act of his comparatively short life was to participate in the establishment of the High School for Boys in Oxford. ${ }^{8}$

For Green, educational institutions needed to play a cardinal role in the development of critical citizens and harmonious social and political life. In an undergraduate essay entitled The Duties of the University to the State, he argued it was the overriding purpose of a university to generate anew principles of thought and action in order to influence and shape public opinion. The university has two duties: to inculcate "...the design of the whole social fabric, and discern in their ever-changing forms those unchanging principles in which the foundations of human life are laid..." and to apply "...these unchanging principles to the various callings of social life, and the common duties of a citizen." $\mathrm{He}$ further remarked that universities should elevate, not mimic or reproduce, public opinion, and educate citizens "...for their work in life, not by teaching them its details, but by informing their minds with those ideas which are embodied in all works alike, or at any rate in their combined results." ${ }^{10}$ Green also insisted education - as a social institution that provides universal access to schools and implements curriculum - can prevent communities from "...splitting up into rival crafts or guilds, solely bent on pursuing class-interests, and inflamed against each other by professional jealousy." "While Green would later modify some of these ideas and ideals - particularly his views on academic specializationthe basic principles underlying his general views on education remained firm. The university should provide moral and intellectual guidance, educators should inculcate the longing for truth, and schools should form citizens rather than consumers, workers, or specialists.

Yet university students do not spring ex nibilo. They emerge from school systems, and Green soon turned his attention to the formative years of education. ${ }^{12}$ Green widely articulated his concerns in lectures, published papers, and community addresses to unravel the various contradictions he considered detrimental to the erection and maintenance of educational institutions predicated on goals

\footnotetext{
${ }^{7}$ T. H. Green, 2003c. Green also praised the Birmingham League:

[i]n its protest against subsidised denominationalism, in its demand that schools supported by public money should be under public management, in its exposure of the low quality of education even in inspected schools, in rousing the public conscience on the question of compulsory education, it claims the sympathy of all friends of education who can distinguish the interests of religion and morals from the interests of the church. (Green, 1891e, pp. 439440)

${ }^{8}$ de Sanctis, 2005, p. 78.

${ }^{9}$ Green, 2003d, pp. 20-21.

${ }^{10}$ Green, 2003d, p. 21.

${ }^{11}$ Green, 2003d, p. 21.

${ }^{12}$ Green along with Arthur Acland, Robert Morant, Michael Sadler, R. B. Haldane, E. G. A. Holmes, and R. H. Tawney "....all helped in different ways, to pioneer a coherent national system of secondary and elementary education, of civic universities and adult education, as well as contributing to the theory of education." (Gordon \& White, 1979, p. x)
} 
such as the promotion of democratic principles and practices. ${ }^{13}$ Three sources of these educational contradictions follow.

\section{Three Systemic Educational Contradictions}

\section{The Wealthy and the Poor}

A decade of reflection and activism by Green about education in the 1870 s revealed how far the distance was between his educational ideals and actual education practices. Green's own experience with elementary and secondary schools and universities led him to promote a system of education that had as its distinguishing mark the goals of individual rights and social equality. A state system of education could address basic educational needs unmet by individuals, groups, and associations, however well intentioned, acting on their own. In his capacity as an assistant commissioner for the Schools Inquiry (or Taunton) Commission, Green soon recognized that funding mechanisms for schools were disparate and thus produced significant differences in instructional delivery. ${ }^{14}$ It was also widely recognized that, of the roughly three thousand public schools in the United Kingdom with endowments earmarked for the poor, many of these endowments were insufficient-either by mismanagement or abuse - to meet their mandates and needs.

The gap between rich and poor required a mediation facility, and Green promoted the establishment of one in Oxford. Such a school would facilitate the transition of students from elementary school to the universities through scholarships based both on material need and merit. Green was deeply concerned about the lack of interest shown by the poor, the middle classes, and the wealthy in the success of the emerging national school system. This contradiction between public apathy and the benefits gained by schooling required a synthesis to increase public awareness. Many of Green's speeches and letters were designed to provide that synthesis, to educate the public about the social benefits of education. ${ }^{15} \mathrm{He}$ wrote: “...the whole of society would gain most thoroughly by the removal of social barriers, by the promotion of a better feeling between class and class, that better feeling which a common education alone can produce." 16 A national, sufficiently funded education system would improve opportunities for the poor, raise education as an issue of national, public interest, and help to harmonize and equalize relations between classes.

Green attributed to the state an important role in providing education resources and opportunities for the youth, but he was no dogmatic advocate of either privately or publicly funded schools. Green believed the state had a positive role to play in removing obstacles to individual selfdevelopment, and the provision of education was the kind of public good that necessitated state

\footnotetext{
${ }^{13}$ Green did not provide a paradigmatic expression of his philosophy of education. Leland explained that Green's public addresses, lectures, and formal writings on moral and political philosophy altogether ...may be spoken of as his attempt towards a philosophy of experience, which after all is an attempt toward a philosophy of education in what is, perhaps, its most fundamental sense. He did not formulate in so many words a statement of his educational ideal, yet he seems throughout his writings to have been reflecting upon the conditions necessary to such a formulation. (Leland, 1911, p. 48)

Gordon and White commented that philosophical idealism "... does not need a separate philosophy of education to go alongside its metaphysics, ethics, and political philosophy. It whole raison d'être is educational." (1979, p. 48)

${ }^{14}$ From 1861 to 1864 the Royal Commission on the Public Schools (the Clarendon Commission) investigated nine public schools. The Taunton Commission on Secondary Education was established in late 1864 to examine endowed grammar schools in England and Wales.

${ }^{15}$ Green, 2003a, pp. 308-309.

${ }^{16}$ Green, 2003b, p. 334.
} 
involvement. Without education individuals could not develop the character necessary to become thoughtful and active citizens. Schools were therefore public goods insofar as they benefited both the community as a whole and its individual members. Green, like most of his Victorian contemporaries, was concerned that state funding of schools could undermine their autonomy-and this was precisely the reason why Oxford and Cambridge universities generally rebuffed efforts at government involvement-but the context and problem area were for Green more decisive policy considerations than abstract principles.

\section{The Secular and the Faithful}

In his Lecture on the Grading of Secondary Schools, Green discussed his experiences with the Taunton Commission. ${ }^{17}$ He explained: "I was then looking forward...to a reconstitution, at no very distant time, of the middle and higher education of England, and... if not to a reconstitution of society through that of education, yet at least to a considerable change in its tone and to the removal of many of its barriers." 18 His main recommendations were to expand the number of secondary schools, to transform Oxford and Cambridge universities into national educational institutions, and to help forge new universities throughout the United Kingdom. After a decade of effort to create a national, uniform, and common system of education, Green soberly remarked "...the hope on which the Oxford reformers of my generation have fondly fed, of drawing from a stratum of society previously unconnected with the university, has been hitherto unfulfilled." 19

Green believed the central obstacle to education reform was the voluntary system that mitigated against a coherent and functional system of schools. From 1780 to 1870, elementary schools in Great Britain were established and maintained by individuals, religious groups, or charitable organizations, although after 1833 government endowments were increasingly being provided. One consequence was that each school district had irregular provisions for education. The wealthier and denominationally active districts were providing education for youth, but other districts lagged far behind. The quality of instructional delivery was uneven, and therefore many promising students were unable to fulfill their academic potential. From the free play of discrete yet powerful religious interests emerged an incoherent system of education that failed to uniformly meet the needs of students and communities. On the one hand, the established Anglican Church with its funds and national organization had many advantages in creating schools at local levels. On the other, religious dissenters such as Independents, Baptists, and Quakers wished to establish their own denominational schools. Consequently, Green observed, "...each school, instead of being one member of an organism, has to act as an independent whole." 20 This state of affairs produced disparate curricula and no universal principles for students and educators to recognize as sources of coherency.

Green's opposition to denominational schools and sectarianism was not based upon what is understood today as secularism in education. He supported religious direction in schools because of the spiritual needs of students and of the potentially integrative power of religious faith. Green's philosophical and humanistic understanding of Christianity meant that doctrinal differences were to be overcome, not reproduced, in schools. ${ }^{21}$ It followed that the state, as the only institution that could legitimately claim to represent the entire community, must mediate between the various churches and sects either to prevent the emergence of or to offset sectarian interests. It was therefore imperative that public funding mechanisms not advantage one group over another. Green insisted the Schools Inquiry

\footnotetext{
17 This lecture was delivered to the Birmingham Teachers' Association and subsequently published in the Journal of Education in May 1877.

${ }^{18}$ Green, 1891 a, p. 387.

${ }^{19}$ Green, 1891a, p. 391.

${ }^{20}$ Green, 1891a, p. 389.

${ }^{21}$ Plant, 2006, p. 26.
} 
Commission's recommendation to create provincial authorities to harmonize the administrative, managerial, and instructional needs of schools would have rectified these problems had it been implemented in its undiluted form.

\section{The State and Parents: Compulsory Education and Free Choice}

The modern objective of compulsory attendance certainly stands in sharp contrast to liberalism's emphasis on free choice and autonomy. Attendance at British elementary schools was voluntary until the passing of the 1870 Elementary Education Act. The policy of compulsory attendance was controversial. Parents, perceiving themselves as having power over their children, defended the right to keep children at home to work and help with the family. Green defended a national system of education as the means to resolving this conflict between the educational needs of children and parental authority. When school boards are established and faithfully represent the people, Green felt, parents will neither consider compulsory school attendance an unnecessary intrusion upon parents' rights nor an infringement of parental authority. Grasping the big picture about the value of education would change the perception of restraint (compulsory attendance) to the recognition of freedom (the self as flourishing, and in command it of its decisions). Attendance must be understood as necessary to student success.

By the mid-1870s, Green was informing audiences and educational associations that sufficient reforms had been made at Oxford University such that access to the institution was as open as he and other similar-minded activists had envisioned. Formal barriers to university entrance no longer applied to religious dissenters, and tuition rates were not beyond the means of a majority of families. ${ }^{22}$ Consequently, Green's reform energies were directed toward primary and secondary education, and he advocated a publicly managed system. His tireless promotion of the teaching of democratic principles influenced both curriculum developments and social policy regarding the inclusion of both genders in public education in his day. The idea that public education would forge equal citizens began to take hold.

\section{Resolving the Contradictions: Policy, Curriculum, and the Self}

The need for principles to resolve educational contradictions was paramount since proposing a public system by itself left unanswered what and how knowledge would be instilled. In his political writings, Green relied heavily on the principle of the common good. If we are capable of recognizing a common good, our having done so identifies us as rational and commits us to supporting it (or so Green would argue). He rejected the view that either individual or social good could be derived from utilitarian premises: that the good derives from the maximum amount of happiness or utility measured by individual preference satisfaction. Green's conception of the common good is an ideal that all in principle share. What is evoked or recognized as the common good must meet three conditions: (a) it must be good for all individuals, (b) no one should gain by another's loss, and (3) loss and gain must be estimated on the same principle for each person. ${ }^{23}$ If good is common to everyone, then the good of others is necessarily related to my own good. In theory, the common good is grounded in the public's recognition that opportunities for individual self-realization should be a universal goal.

\footnotetext{
22 Green helped form a "Lectures for Women" committee in 1873, and with Charlotte Green (his wife) helped found in 1879 Somerville Hall (renamed Somerville College in 1894), one of the first colleges for women in Oxford. Women still were not admitted to Oxford University as degree-earning students until after the First World War; see Leighton, 2004, p. 61.

${ }^{23}$ Green, 1883, §240.
} 
For Green, a public system of education would create an institutional setting for the recognition of mutuality between the poor, the middle class, and the wealthy, and between the universities and the nation itself. Yet he noted that this recognition of mutuality would not likely arise spontaneously. Mutuality requires not only systemic links between citizens, associations, institutions, and governments, but also conscious recognition of those links as constitutive and informative. The recognition of mutuality is necessary to address the tensions between internal limitations (the development of individual talents and capabilities) and external constraints (formal barriers to education). For mutuality to flourish, common ground must be found: perhaps in recognizing a contradiction, or formulating a curriculum focus, or sharing a goal that illuminates our mutuality. For example, we must all value justice at some level to talk about its inculcation. The recognition of mutuality can become embedded in the development and implementation of curriculum. There must be principles that override personal and private preferences in education.

The policy dimensions of the common good must be worked out by those responsible for educating students to comprehend the common good. The practical problem that arises is who is to educate citizens to recognize the common good. Certainly Green's writings and speeches indicate he was not sanguine of the prospects of powerful and influential social, political, religious, and economic groups and associations claiming the fulcrum of the common good. The agents charged with the task, it would seem, are teachers at the primary, secondary, and post-secondary levels whose main responsibility is to unlock student potential and explore the meaning of social and political life. We turn now to elaborate the philosophical theory that Green established as the basis of reform.

\section{Freedom as a Goal of Education}

For Green, education is a process whereby individuals acquire the freedom to determine their futures. Green's conception of freedom was shaped by diverse sources including Locke, Kant, and Hegel. Hegelian freedom is the pure act of thought, the awareness of our conscious powers to be and to act in the world. Ultimate freedom of thought occurs when thought makes itself its own object, for in that act the contradictions that structure experiences are unavoidably revealed in consciousness, a revelation that for Hegel is the meaning of truth. The oppositions that form possible experiences-form and content, the extrinsic and the intrinsic, rational restraint and free choice-determine objects of thought. In grasping this necessity of thought process one transfigures the meaning of freedom. ${ }^{24}$ The idea of free choice, for Hegel, is a contradiction. Choosing is an act of thought without content and therefore not about anything, and if it is about something, then the content of thought is the determinant of choice. ${ }^{25}$

Green, pressed by the need for contemporary social analysis, formulated the concept of freedom in his own terms. Freedom involves the self as a thinking agent and also as inextricably related to other selves. If we consider other selves as constraints, as negations of our goals, we are not free. We constantly struggle to overcome the contradiction of being self-aware and inwardly individuated. Yet we have to think and act in the world that limits us. We can neither avoid nor negate social relations: Green posited relations as the product of consciousness. The unity of nature and knowledge is grounded with consciousness as a universal phenomenon. Whatever presents itself to us is made intelligible by conceptually locating and relating it to what is already known by a particular consciousness. ${ }^{26}$ Relations of dependency and independency are necessary to the formation of one's understanding of self. One

\footnotetext{
${ }^{24}$ See Hegel, 1991, §38-40.

25 Hegel's example to illustrate the shift from external constraint to internal understanding, and hence the experience of freedom, is helpful: "A criminal, when punished may look upon his punishment as a restriction of his freedom. Really the punishment is not foreign constraint to which he is subjected, but the manifestation of his own act: and if he recognizes this, he comports himself as a free man." (Hegel, 1975, p. 283).

${ }^{26}$ Green explores this theory in Green, 1884, \$1-8.
} 
cannot have a truthful understanding of one's self without overcoming the oppositions that others seem to represent by acknowledging and then constructing relations between oneself and others. Freedom is enhanced as one grasps the essentialness of others to one's very existence as a selfdetermining agent.

If we momentarily set aside Green's formal theorizing about the nature of freedom, we can recast what he is attempting to demonstrate. By viewing the self as at least partly constituted by what it considers to be its interests, and moreover recognizing that the self is situated in an environment where there will be both cooperation and conflict in realizing interests, we must appreciate the extent to which the self is capable of participating in the context of cooperative and competing human activities. Yet it is preferable that selves distinguish between their wants or needs and interests and express them to others. Green understands that an individual's interests will not always be consistent with her needs and therefore the development of selves should be predicated on ensuring there are institutional and social mechanisms to encourage self-examination and critical awareness of interests that are, as best as can be, matched with human needs. More important, if the goods that individuals seek are located within a context of cooperation and conflict, then every interest has political and social dimensions that require selves to assess areas where there will be cooperation and conflict and formulate courses of action.

In Green's time, a prominent utilitarian view was that society is as an aggregate of individuals in which the sum of the discrete interests of its members represents the public interest or good. Green's goal was to reconsider the meaning of the individual in society by emphasizing both the individual and societal character of interests and needs. In place of exclusively individuated interests, Green stressed what we can call the principle of mutual independence. His idea of mutually independent and necessary relations between self, others, and the community became an integral component of a transformation in late nineteenth-century liberalism, a transformation Green himself played a substantial role in bringing about. The principle of mutual independence could be used to address the structural and systemic sources of poverty and unemployment, to promote access to education, and to reveal the societal forces that shape an individual's development. Green argued that individuals should be governed in their actions by their grasp of their place in a community sustained by the principle of mutual independence. This recognition would balance the goal of forging independent and self-reliant selves with other-dependent relations and thus provide a better foundation for citizenship pedagogy.

\section{Reform and Democracy}

If Green's theory is convincing, then reforms in policy areas such as education, housing, working conditions, and poverty must be everyone's concern. "Everyone" meant using the state (in theory, all) and legislation (born of democratic institutions to express the will of the community) to achieve social and economic policy objectives. Green fully supported the liberal ideal of autonomous selves in that he insisted the state could not forge an individual's moral character. His self-realization ethic is predicated on the development and exercise of individual judgment. The moral self must rationally and freely choose right courses of action. Governments nonetheless have a legitimate and necessary role to play in shaping (and circumscribing) the general political, social, and economic conditions within which individuals are situated. The state can address social and economic circumstances, but the relations between people must be governed by individuals. ${ }^{27} \mathrm{~A}$ public education system could address barriers to self-development or, in Green's term, "self-realization" (an idea to which we will return). The role of the state is to create and to secure the social, political, and economic conditions in which individuals can develop their latent capacities and capabilities to the fullest extent possible. The concept of being a citizen (and by "citizen" Green meant someone who possesses legal rights to vote and to serve on a

\footnotetext{
27 Green insists the "...real function of government [is] to maintain conditions of life in which morality shall be possible, and morality [consists] in the disinterested performance of self-imposed duties....” (Green, 1986, \$18).
} 
jury and who is committed to the principles and virtues of democracy) is the outcome of the unifying relations of mutual independency, which is also the basis of individual equality. ${ }^{28}$

That communities need citizens who recognize and practice virtues is by no means an original idea. It is, however, noteworthy to suggest that teachers not only teach facts or train carpenters, but also shape metaphysical visions and play a crucial part in creating citizens. For Green, the contradiction of state (source of power and restraint) and citizen (source of ideas, labour, and individual agency) could be resolved through the recognition of democratic principles as a necessary element of community identity. In non-democratic states, self and other remain in a state of perpetual suspicion and fear. If we agree about the value of participating in decision-making because we recognize that participation furthers our freedom, then participation is a vital relating activity. Such a notion consequently has deep and profound implications for educational theory and practice.

\section{From Theory to Practice}

Can Green's philosophy translate into practical application for educators today? The challenge for educators is to offer opportunities to individuals to create their own system of relations and their own flourishing network of principles grasped and interests pursued while nurturing mutual independency. The child needs to develop as uniquely and differently as she can but avoid developing relations to other children and adults that cast them as inherently threatening. For the child, the contradiction that looms is how to be both the same and different.

Consider some examples of what Green's claims indicate about classroom experiences and the development of good character. The first such consequence revolves around interpersonal relations between the teacher and student. One such barrier (we suggest) is the hypocrisy and double standards of classroom practices and etiquette. A child may be compelled to adopt social relations and conduct established by adults, but the child needs consciously and actively to adopt them. If not, accepted conduct may be chosen merely for individual gain or to please others, both of which are contrary to Green's self-realization ethic. For example, requiring children to be polite and respectful in accordance with tradition or custom (or fear of punishment), yet allowing adults to flout such social customs, can result in such conduct appearing not as an inherently valuable social practice but instead a privilege of power. A teacher who denigrates students or openly demonstrates hostility can extract polite behaviour from students. Yet while students may demonstrate obedience in this context, it almost certainly imparts a distorted power relation.

If equal opportunity is to be meaningful, then experiences that expose the child to understanding equality (and inequality) must be part of her self-development through relation constructions. For example, a child can experience the results of both merit-based and equal- opportunity policies in classroom activities. As parents and educators well know, children are not tiny bundles of altruism. The challenge is to determine the appropriate points where the meritorious and fairness principles are to be applied. Meritorious principles of distribution do not always allow for equal opportunity. Repeated exposure to distributive practices creates relations between the child and others in the classroom. If a child is not deemed merit worthy, then opportunities for participation are limited, as are the intrinsic and extrinsic goods that flow from classroom projects and activities. Double standards, such as those that champion equality and yet reward (and thus encourage) merit-based activities in the classroom do

\footnotetext{
${ }^{28}$ Leland commented that Green's philosophy ...takes its place as a vindication in the growing social democracy of England, of the right of every human being to an education according to his capacity.... Without the right to an education the child lacks the opportunities which are the very basis of his moral development-his participation in the common good. A child's rights are in proportion to what there is in him to become. This indicates an educational democracy-a school democracy of equal opportunity. (Leland, 1911, p.53).
} 
raise questions about the authenticity of any educational efforts at socialization. It is not surprising that students become cynical, hostile, and apathetic. Reform in education must result in the creation of students who have constructed for themselves their necessary bonds to the standards of conduct expected in communities committed to rights, equality, and respect. We turn now to Green's principle of individual self-realization, which provides an alternative perspective on forging student experiences.

\section{Educating Selves in the Common Good}

\section{Realizing the Self}

One implication of Green's conception of individuality is that the interests, needs, and desires that define individuals are shaped by the limitations and possibilities of political and social institutions. Citizens are reflections of the limitations of liberal-democratic discourse and practice as much as the possibilities inherent in liberal-democratic institutions. Our needs, interests, and desires are shaped and circumscribed by membership in groups and associations, the discursive and structural norms of such groups and associations, and the broader system of social norms and values. Our interests and preferences will be shaped and formed not simply in the exercise of choice itself but also by the opportunities and limitations imposed on us. Freedom consequently is a social capacity that individuals will develop through interactions with others by recognizing both difference and identity, by acknowledging others as separate selves with their own discrete capacities and interests, and by appreciating areas where we can speak of sharing some experiences and interests.

"Individual self-realization" for Green is an institutional process of providing the ideal context and setting for individuals to achieve their latent capacities and powers. Avital Simhony has provided a three-fold explanation of individual self-realization: a) it requires a view of shared social life whereby individual self-development is achievable only in conjunction with others; b) this "good" is common to all members of a given community; and c) the good pertains to each member individually, not the community as a whole. ${ }^{29}$ Applying individual self-realization to the context of education reveals Green's objective was not that all students should receive the same or an identical education. Individual self-realization cannot be achieved under such conditions. If students who do not qualify for university or college find their vocations, but had genuine opportunities to advance in their elementary and secondary education, then the standards established by individual self-realization have been met. ${ }^{30}$ Green's conception of the common good is shaped by the liberal presumption of individual selfinterest, yet also provides a deeper, richer understanding of relations with others. For Green it is natural that a perpetual process of differentiation and integration occurs in relationships between the individual and society and between individuals.

There is a close relationship in Green's theory between individual self-realization and the common good, but one complicated by the range of human goods he identifies. Green appears to discuss at least three conceptions of the good. The first is what we can call individual goods that are material, scarce, and generate claims to exclude others from use such as property. These individual goods Green recognizes as necessary to achieve discrete individual goals, although they are not strictly

\footnotetext{
${ }^{29}$ Avital Simhony, 2001, pp. 72-73.

${ }^{30}$ Nicholson, 1990, p. 174. Green would concur with J. S. Mill who remarked in his On Liberty that [t]o be held to rigid rules of justice for the sake of others develops the feelings and capacities which have the good of others for their object. But to be restrained in things not affecting their good, by their mere displeasure, develops nothing valuable except such force of character as may unfold itself in resisting the restraint. If acquiesced in, it dulls and blunts the whole nature. To give fair play to the nature of each, it is essential that different persons should be allowed to lead different lives. (Mill, 1978, pp. 60-61)
} 
speaking moral goods because they entail competition. Green also recognizes another series of human goods that can be designated as public goods such as parks, roads, health, and education. The remaining good is what Green has been referring to as a common good. Green speaks of the common good as one that does not admit competition, such as the pursuit of individual goods, yet is both individual and social in nature. What kind of goods would meet this condition? Green identifies a number of such human goods, including shared heritage and history, language, national culture, religion, membership in professional and social associations, and citizenship. Perhaps most important of these would be a general system of rights and freedoms that requires social recognition. ${ }^{31}$ The significance of maintaining a system of rights and freedoms, and its implications for education, will be examined shortly.

The task for today's teacher charged with teaching children how to comprehend the common good, guiding the exploration of their potentials, and then imparting to students that it is in their interest to acknowledge others' interests, seems Herculean if not Sysiphean in scope. Children, for the most part, will tend instinctively to value 'mine' over 'thine.' Moreover, what might be achieved in one class can be destroyed in the next. Has Green posed the ultimate contradictory principle as the focus of curriculum planning and classroom pedagogy-that self-interest and the common good can be understood as logically and necessarily related?

\section{The Self and Others}

According to Green, the first condition of experience is the self, and individual self-consciousness supplies the distinction between self and other, self and nature, and self and social environment. Children come to recognize that there are others in the world competing with them to fulfill their desires. ${ }^{32}$ They confront their first contradiction early when they distinguish between 'mine,' 'thine,' and 'ours.' This discovery is complicated by the fact that what is mine may be, both in class and elsewhere, only temporarily so. That is what conflict and cooperation entail. Children enter the world and the world of the classroom experiencing a perpetual contradiction, being both the self that seeks to act in the world — to seek experience and understanding — and the self that resists the limitations of othersthe self that wants to individuate itself.

The fact of being a self-conditioned or free energy acting under limiting conditions can produce a sense of perpetual self-contradiction between what one is and what one could be. Children confront this fact at every turn. There are always standards and expectations, performances and achievements, all of which make self-development a source of both disappointment and pride. The contradictory relations of success and failure have to be sustained on a daily basis. Our recognition of this contradiction generates the impulse or need both for knowledge and goodness-more knowledge to understand the source of contradictions, and goodness that recognizes human error with knowledge of the benefits of forgiveness and mercy. The perceived contradictions between self and other, between knowledge and ignorance, may be overcome or at least mitigated if students can be educated to search for truth, however discomforting it may sometimes be, and to will what is unselfish.

The demands on a teacher to explain such contradictions reside uneasily with the need to establish authority and classroom discipline and to reward performance and excellence. Helping children to seek their own self-individuation and yet see others as integral to achieving their goals requires problem solving within the context of conflict and cooperation. Cooperation and respectful competition, time afforded to explain notions of dependency, and consistent classroom practices (not

\footnotetext{
31 See Nesbitt, 2001.

32 Green is working out the practical implications of Hegel's theory of the self. Selves for Hegel become selfconscious only in relation to nature, to other similar conscious selves, and to the universal spirit in the world; see Hegel, 1966, pp. 219-266, especially p. 226. Leighton demonstrated that Green also was influenced by Ferdinand Christian Baur, a German theologian and founder of the Tübingen school of theology; see Leighton, 2004 , p. 53. For a later neo-Hegelian (F. H. Bradley) theory of the self, see Trott, 1996.
} 
"two-faced" classroom rules) must become part of a child's daily, indeed hourly, experiences in order to establish the dialectic of self and others. A child's earliest exposure to authority beyond the home (and religion) is in the classroom, and her experiences there inevitably initiate constructions of relations with others. To create a community in the classroom, classroom practices must be seen as supportive of selves in conjunction with others, with some understanding of the common good being promoted. Green's theory would suggest that the relation between competition and self-realization has to be very carefully balanced. The long-term effects of selves "developed" under excessively competitive circumstances may include both realized selves and an array of unrealized selves, conditions which hardly further appreciation of the common good.

\section{The Self, Rights, and the Common Good}

Education frees individuals. If limitations can be acknowledged and addressed, then ideas, decisions, and actions may overcome circumstances. Green's evocation of a common good indicates that a properly educated self is one that can distinguish between self and others, can assess courses of actions and interests in terms of what is best, ideal, or perfect, and can then transcend its own interests and values and measure them by reference to others' interests, values, and goods. To adopt these objectives, there must be some evidence or manifestation of this common good. Green's political theory suggests that a system of individual rights is sufficient evidence of such a common good.

The rights relationship formed between individuals is foundational to liberal-democratic citizenship. Rights relations and claims are the principal means by which conflicting political, social, and economic values and interests are articulated and resolved. What are rights? At the most basic level, rights are claims to something or from something. For example, a right to a peaceful social and political environment involves both a claim to be secure and a claim against decisions and actions that would undermine or threaten security. Green's originality as a rights theorist derived from his recognition that individual rights have individual and social dimensions. Rights for Green are recognized claims to some individual or social good acknowledged in customs, traditions, and laws. The evolution of individual, human rights presupposes that individuals are equal to the extent they are capable of participating in broad dialogue about claims (and counter-claims) to be treated in certain ways.

A child therefore needs to understand and identify with the rights-duty relationship. This poses a new contradiction for the teacher: introducing rights-based dialogue while perpetually limiting the child's sphere of actions. Such limitations can be: mental, through introducing progressively more difficult assignments; emotional, by requiring emotional restraints on the child but not always the teacher; and physical, such as demanding more sitting at desk work and less moving around. In the face of such limitations, what discussions and activities can students perform to further their understanding of their individual rights and the rights of others? Do they grasp the discourse of rights as both individual and social in nature? Exposure to the goods that accrue from community (read classroom) negotiations over shared problems can be beneficial and some semblance of participating in community goods can be experienced in classrooms that encourage such activities.

How then can teachers guide students to deepen their understanding of rights discourse and citizenship? Simulations are powerful pedagogical tools. Parliamentary simulations-having students assume roles such as the prime minister, opposition leaders, and backbenchers - can be engaging but have a tendency to focus on debate and conflict rather than compromise and agreement. This should not be surprising since parliamentary governments within Canada normally compromise in legislative committees or privately with opposition and house leaders. Only the most discerning of observers can recognize when public officials are cooperating. Another form of simulation offers great promise: constitutional dialogue. The effort in Canada to amend the constitution in the early 1990s - the Charlottetown Accord-ultimately failed insofar as Canadians rejected the proposed constitutional changes through a nation-wide referendum, but the process revealed that future constitutional change almost assuredly will involve active involvement by citizens and groups. A properly conceived and 
constructed exercise where, for example, students create a classroom bill of rights would place them precisely in a situation entailing both conflict and cooperation.

There is currently little in the educational experience that exposes children to the intrinsic or extrinsic value of shared dialogue, negotiation, challenge, compromise, and consensus-building. This is the greatest challenge of educating for democracy. The necessary counterpoints of individual successthose individuals who pave the way, and those trampled by the paths laid by others-fade in the clamor of individuated articulations. The task of promoting participatory democracy within the telos of individual success frames the ultimate contradiction for the educator.

\section{From Theory to Practice: Some Difficulties}

Green's championing of individual self-realization and the common good presumes that the best, the perfect, and the ideal are recognizable. However, one may chose to realize oneself in ways incomprehensible to others. Green acknowledged this problem when he remarked that self determination is equally attributable to "...the man whose will is heteronomous or vicious...." 33 Green assumed that true individual self-realization would be regarded as a moral principle in that the well being of others would be understood as necessary to fulfilling one's own interests. His remarks about self-development of character (and the state's inability to impose moral character) anticipate that individual whose sense of self has been built on a set of inconsistent relations. One may seek to realize oneself as an artist and an addict. Those who have combined such goals-Billie Holiday, Charlie Parker, Chet Baker, Ernest Hemmingway-lived and created while totally dependent on others but appeared quite indifferent to that dependency. Green insists rationality and knowledge are measures of the realized self. The common good (in relation to individual self-realization) is a meaningful concept only in a society that institutionalizes the dialectical necessity of reason, knowledge, and choice- the touchstones of democracy.

\section{Thought and Action: The "Old Antagonism"}

\section{The Individual and the Masses}

The distinction between thought and action (which finds its roots in Plato and Aristotle) represents perhaps the most basic tension in education. Is education for the sake of knowledge, or is education meant to train people for skills development? This question remains relevant with respect to mass education. Green attempted to bridge the "...old antagonism between speculation and action..." 34 by distinguishing between the theoretical or speculative and the practical or moral. Theoretical or speculative knowledge involves efforts to know and to understand, and includes science, philosophy, and art. The practical or moral involves practical activities that aim to better the self or to create a better condition. The desire to transform and to improve our lives is the goal of knowledge and understanding. For Green, art, philosophy, and religion seek to attain perfection, a state of being that involves a fusion of thought, action, and objects. When artists create works, when philosophers expose paradoxes, and when religious leaders inspire their congregations, what is created is something new and different-a genuine creation.

Green was concerned that the impetus to mass production within modern societies in both the arts and the sciences would undermine genuine creation. Individuals, he insisted, are not "...passive

\footnotetext{
${ }^{33}$ Green, 1891 b, p. 309.

${ }^{34}$ Green, 1891 d, p. 35.
} 
receptacles of natural impressions..." and consumers of resources, but rather are "...constructive and free...." 35 In words that resonate today, Green explained that we

...hear much in these days of the sacrifice of the individual to society through professional limitations. In the progressive division of labour, while we become more useful as citizens, we seem to lose our completeness as men. The requirements of special study become more exacting, at the same time that the perfect organization of modern society removes the excitement of adventure and the occasion for independent effort. There is less human interest to teach us within our calling, and we have less leisure to seek it beyond. ${ }^{36}$

\section{Elsewhere, Green remarked that the}

...details of all professions are alike out of place in a University education, but a knowledge, not merely of the natural laws exhibited in their work, but of the ultimate ends of social life, is necessary to emancipate the tradesman and artisan from the bondage of daily routine, and to make them work with full energy and intelligence as citizens. ${ }^{37}$

Yet Green's practical involvement with school reform led to a somewhat different conclusion about training and specialization. He recognized different levels of secondary schools are necessary because people will choose their own vocations. In other words, different selves construct their worlds on the basis of different interests and needs. The practical tensions between general and specialized knowledge were a matter of concern for Green. He would have viewed any effort to create separate schools focussing on, for example, business and commerce as counterproductive because commerce and trade can facilitate the development of impartiality by thrusting individuals into networks that involve the evaluation of the interests of self and others in pursuit of plans and projects. Moreover, Green argued trade and commerce equalize citizens by breaking down class distinctions and by advancing practical knowledge of society. ${ }^{38}$ Leland noted this universalistic feature of Green's thought when she wrote that educational theory is not an effort

...to digress from facts; it is an attempt to get closer to them by showing them in their broader setting and relations, and thus revealing their meaning. In the present age of specialization which extends even to the field of education, there is the danger of one man seeing the facts of his own particular line of work without realizing their significance in the whole of reality, and thus there is the possibility of his conceiving his own little share in the whole as if it were the whole. This may account at least partially for the fact that many special school supervisors can see nothing except the special subjects which they are supervising and cannot therefore adjust these subjects with any sense of proportion to the rest of the curriculum. ${ }^{39}$

In promoting such a view, Green anticipated the educational reforms and developments of the twentieth century. If democracy means each citizen should vote with some understanding of the issues, and see how they relate to other issues and persons, then each individual must be educated in order to become a knowledgeable and contributing citizen.

\footnotetext{
${ }^{35}$ Green, 1891c, p. 112.

${ }^{36}$ Green, 1891 d, p. 40.

${ }^{37}$ Green, 2003d, p. 21.

${ }^{38}$ Green, 2003e, p. 3.

${ }^{39}$ Leland, 1911, p. 54. The emphasis is original.
} 


\section{The Democratic Self: The Classroom Challenge}

To become a democratic self one must participate in the construction of democratic relations between oneself and others. How is a developing child to experience that crucial development towards valuing the universality of such experiences without the opportunity to experience the benefits to the self and others on a daily basis? Sporadic voting after one reaches voting age is not enough. By the time one is old enough to vote, the reasons to do so may have been stifled in the world of disparate, random facts and self-aggrandizement. In Green's view, individual interests and common good are not opposite forces but are the precursors to moral and social development. The perpetual dialectical conflict will result in the emergence of a higher good. The implication for educators is clear: they fail in their task if students are taught that individual interests and needs are irreconcilable with others' interests and needs.

\section{Whither Democracy?}

Green uniformly stressed that the good life cannot be gained in isolation but only through participation in the various associations and institutions that comprise society. The school is one of the most basic social institutions. Schools embody curriculum development and implementation, and the very purpose, ideas, and ideals of the community in which they reside. What is important about Green's recognition of the tensions between the basic objectives of education-the intrinsic and extrinsic objectives-is that he anticipates and confronts some of the challenges of modern mass education. Can mass education create democratic citizens? The necessary antagonisms and tensions in education and the intrinsic value of knowledge require teachers to convey to students the fact that individual interests must be balanced and harmonized, and that the individual's good is intimately related to the recognition of others' goods. Democracy formalizes this recognition as a form of common good, one that encourages individual decision-making about community life, the life that makes human and humane life possible.

\section{Acknowledgments}

This paper was originally prepared for the 2005 Idealism Today conference at Harris Manchester College, Oxford University. The authors express their gratitude to those conference participants, especially Peter Nicholson, who provided feedback and critical comments.

\section{References}

Adsett, Margaret (2003). Change in political era and demographic weight as explanations of youth 'disenfranchisement' in federal elections in Canada, 1965-2000. Journal of Youth Studies, 6 (3), 247264.

de Sanctis, Alberto (2005). The 'puritan' democracy of Thomas Hill Green. Exeter: Imprint Academic.

Dudley, Robert, \& Gitelson, A. R. (2004). Political literacy, civic education, and civic engagement: A return to political socialization? Applied Developmental Science, 6 (4), 175-182.

Esquith, Stephen L. (1994). Intimacy and spectacle: Liberal theory as political education. Ithaca: Cornell University Press.

Galston, William A. (2001). Political knowledge, political engagement, and civic education. Annual Review of Political Science, 4 (1), 217-234. 
Gordon, Peter, \& White, J. (1979). Philosophers as educational reformers: The influence of Idealism on British educational thought and practice. London: Routledge \& Kegan Paul.

Green, Thomas H. (1883). Prolegomena to ethics (A. C. Bradley, Ed.). Oxford: Clarendon Press.

Green, Thomas H. (1891a). Lecture on the grading of secondary schools. In Thomas H. Green, Works of T. H. Green: Vol. III (R. L. Nettleship, Ed.; pp. 387-412). London: Longmans, Green and Co.

Green, Thomas H. (1891b). On the different senses of 'freedom' as applied to will and to the moral progress of man. In Thomas H. Green, Works of T. H. Green: Vol. II (R. L. Nettleship, Ed.; pp. 308-333). London: Longmans, Green and Co.

Green, Thomas H. (1891c). Popular philosophy in its relation to life. In Thomas H. Green, Works of T. H. Green: Vol. III (R. L. Nettleship, Ed.; pp. 92-125). London: Longmans, Green and Co.

Green, Thomas H. (1891d). An estimate of the value and influence of works of fiction in modern times. In Thomas H. Green, Works of T. H. Green: Vol. III (R. L. Nettleship, Ed.; pp. 20-45). London: Longmans, Green and Co.

Green, Thomas H. (1891e). Two lectures on the elementary school system of England. In Thomas H. Green, Works of T. H. Green: Vol. III (R. L. Nettleship, Ed.; pp. 413-455). London: Longmans, Green and Co.

Green, Thomas H. (1986). Lectures on the principles of political obligation (P. Harris \& J. Morrow, Eds.). Cambridge: Cambridge University Press.

Green, Thomas H. (2003a). Education in Oxford, 17 November 1876. In Thomas H. Green, Miscellaneous writings, speeches and letters (P. P. Nicholson, Ed.; pp. 285-286). Bristol: Thoemmes Press.

Green, Thomas H. (2003b). Liberal politics in Oxford; The new high school for boys, 8 October 1878. In Thomas H. Green, Miscellaneous writings, speeches and letters (P. P. Nicholson, Ed.; pp. 330-335). Bristol: Thoemmes Press.

Green, Thomas H. (2003c). National education, 27 January 1870. In Thomas H. Green, Miscellaneous writings, speeches and letters (P. P. Nicholson, Ed.; pp. 236-238). Bristol: Thoemmes Press.

Green, Thomas H. (2003d). The duties of the university to the state. In Thomas H. Green, Miscellaneous writings, speeches and letters (P. P. Nicholson, Ed.; pp. 20-22). Bristol: Thoemmes Press.

Green, Thomas H. (2003e). The effect of commerce on the mind of a nation. In Thomas H. Green, Miscellaneous writings, speeches and letters (P. P. Nicholson, Ed.; pp. 3-5). Bristol: Thoemmes Press.

Hegel, Georg W. F. (1991). Elements of the philosophy of right (H. B. Nisbet, Ed.). Cambridge: Cambridge University Press.

Hegel, Georg W. F. (1966). The phenomenology of mind (J. B. Baillie, Trans.). London: Allen \& Unwin.

Hegel, Georg W. F. (1975). Hegel's logic (W. Wallace, Trans.). Oxford: Clarendon Press.

Leighton, Denys P. (2004). The Greenian moment: T. H. Green, religion and political argument in Victorian Britain. Exeter: Imprint Academic.

Leland, Abby Porter (1911). The educational theory and practice of T. H. Green. New York: Columbia University.

Meirick, Patrick C., \& D. B. Wackman (2004). Kids voting and political knowledge: Narrowing gaps, informing votes. Social Science Quarterly, 85 (5), 1161-1177.

Mill, John Stuart (1978). On liberty (E. Rapaport, Ed.). Indianapolis: Hackett Publishing Company.

Nesbitt, Darin R. (2001). Recognizing rights: Social recognition in T. H. Green's system of rights. Polity, 33 (3), 423-437.

Nicholson, Peter P. (1990). The political philosophy of the British Idealists. Cambridge: Cambridge University Press.

Patrick, John J. (2002). Political socialization of youth: Reconsideration of research on the civic development of elementary and secondary school students in the United States and abroad. The International Social Studies Forum, 2 (1), 59-65.

Plant, Raymond (2006). T. H. Green: Citizenship, education, and the law. Oxford Review of Education, 32 (1), 23-37. 
Sapiro, Virginia (2004). Not your parents' political socialization: Introduction for a new generation. Annual Review of Political Science, 7 (1), 1-23.

Simhony, Avital (2001). T. H. Green's complex common good: Between liberalism and communitarianism. In Avital Simhony \& D. Weinstein (Eds.), The new liberalism. (pp. 69-91). Cambridge: Cambridge University Press.

Trott, Elizabeth (1996). The self and the social order. In Philip MacEwan (Ed.), Ethics, metaphysics and religion in the thought of F. H. Bradley (pp. 110-121). Lewiston, NY: Edwin Mellon Press.

Warren, Mark (1992). Democratic theory and self-transformation. American Political Science Review, 86 (1), $8-23$.

\section{About the Authors}

Darin R. Nesbitt (nesbittd@douglas.bc.ca) teaches political science at Douglas College and Elizabeth Trott (etrott@arts.ryerson.ca) teaches philosophy at Ryerson University. 